\title{
Faktor Determinan Yang Berpengaruh Terhadap Pencemaran Sungai Musi Kota Palembang
}

\author{
Heri Setianto, Husni Fahritsani \\ Masuk: 26092019 / Diterima: 13122019 / Dipublikasi: 31122019 \\ (c) 2019 Fakultas Hukum dan IImu Sosial UNDIKSHA dan IGI
}

\begin{abstract}
The increasing number of population and the high development activities in the city of Palembang has increased industrial activities, settlement activities, and other activities that make an increase in the amount of waste generated every day. The problem in this research is the determinant factors that most influence the Musi River pollution in Palembang City. The method used in this research is the case study method with a survey approach. Primary data obtained from field research and laboratory analysis include TDS, TSS, pH, Iron (Fe), Lead (Pb), Ammoniac (NH3-N) Phosphate $(P O 4-P), D O, C O D, B O D$, and total Coliform concentration. The results of the study are the most dominant chemical elements, namely iron elements in river water, iron elements between $288 \mathrm{mg} / \mathrm{l}$ to $453 \mathrm{mg} / \mathrm{l}$. The highest concentration of ammonia is at sample point 1, which is located downstream of the Musi River; high levels of ammonia are sourced from industrial activities and domestic household activities. The COD concentration in the Musi River water is above the standard threshold of $97 \mathrm{mg} / \mathrm{l}$. Concentrations that exceed other thresholds, namely BOD and DO concentrations. This condition can be caused by the decomposition of organic elements contained in river water. The results of the study concluded that the determinant factors that have a significant influence on the pollution of the Musi River are household waste factors, and the second determinant factor is industrial factors.
\end{abstract}

Key words: Determinant Factors; Water Quality; Musi River

Abstrak Semakin bertambahnya jumlah penduduk dan tingginya kegiatan pembangunan di Kota Palembang mengakibatkan semakin meningkatnya kegiatan industri, kegiatan permukiman, dan kegiatan lainnya yang menjadikan peningkatan terhadap jumlah limbah yang dihasilkan setiap harinya. Masalah dalam penelitian yaitu Faktor -faktor determinan yang paling berpengaruh terhadap pencemaran Sungai Musi di Kota Palembang. Metode yang digunakan dalam penelitian ini adalah metode studi kasus dengan pendekatan survai. Data primer diperoleh dari hasil penelitian di lapangan dan hasil analisis laboratorium meliputi konsentrasi TDS, TSS, pH, Besi ( $\mathrm{Fe})$, Timbal (Pb), Ammoniak (NH3-N) Phosphate (PO4-P), DO, COD, BOD, dan konsentrasi Colyform Total. Hasil penelitian yaitu unsur kimia yang paling dominan yaitu unsur besi dalam air sungai, unsur besi antara $288 \mathrm{mg} / \mathrm{l}$ sampai dengan $453 \mathrm{mg} / \mathrm{l}$. Konsentrasi Amoniak tertinggi berada pada titik sampel 1 yang terletak pada hilir Sungai Musi, tingginya kadar amoniak bersumber dari kegiatan industri dan kegiatan domestik rumah tangga. Konsentrasi COD pada air Sungai Musi berada diatas ambang batas normal yaitu 97 $\mathrm{mg} / \mathrm{l}$. Konsentrasi yang melebihi ambang batas yang lain yaitu konsentrasi BOD dan DO. Kondisi ini dapat disebabkan oleh dekomposisi unsur organik yang terdapat dalam air sungai. Dari hasil penelitian disimpulkan bahwa faktor determinan yang berpengaruh utama terhadap pencemaran Sungai Musi yaitu faktor sampah rumah tangga dan faktor determinan yang kedua adalah faktor indistri.

Kata kunci : Faktor Determinan; Kualitas Air; Sungai Musi

\section{Pendahuluan}

Sungai merupakan tempat

berkumpulnya air dari lingkungan sekitarnya yang mengalir menuju tempat

Heri Setianto, Husni Fahritsani

Universitas PGRI Palembang

setianto.heri8@gmail.com yang lebih rendah. Dari proses penggunaan lahan, bagian hulu sungai pemanfaatan lahannya bersifat lebih sederhana dan alami seperti hutan dan perkampungan kecil sedangkan daerah tengah dan hilir sungai biasanya kegiatan pemanfaatan lahan meningkat seperti permukiman maupun pertanian. Sejalan dengan hal tersebut suplai limbah cair dari 
daerah hulu yang menuju ke daerah hilirpun menjadi meningkat. Pada akhirnya daerah hilir merupakan tempat akumulasi dari proses pembuangan limbah cair yang dimulai dari hulu (Agustine, Sudirja, \& Harryanto, 2018). Kegiatan pembangunan yang semakin berkembang berdampak pada peningkatan jumlah penduduk sehingga terjadi penutupan permukaan tanah, mempersempit daerah resapan air, dan terjadi peningkatan penggunaan sumberdaya alam. Salah satu pencemaran yang dapat terjadi sebagai dampak adanya kegiatan pembangunan adalah pencemaran perairan (Mahyudin, Soemarno, \& Prayogo, 2015). Selain itu dengan adanya kegiatan pembangunan industri akan mengakibatkan paparan logam berat kedalam sungai (Casali et al., 2010; Yudo, 2010).

Kegiatan industri dan aktivitas manusia akan meningkatkan jumlah buangan atau polutan ke perairan dan merusak lingkungan (Mamun \& Zainudin, 2013). Selain itu, sungai sebagai tempat penampungan air mempunyai kapasitas tertentu dan ini dapat berubah karena aktivitas alami maupun aktivitas antropogenik. Biasanya pencemaran yang terjadi di sungai berasal dari beberapa sumber diantaranya yaitu (a) tingginya konsentrasi sedimen yang berasal dari erosi tanah, kegiatan pertanian, penambangan, kegiatan konstruksi, pembukaan lahan baru dan kegiatan lainnya yang dapat menimbulkan pengelupasan lapisan tanah; (b) limbah organik dari hasil proses kegiatan domestik manusia, limbah dari hewan dan tanaman; (c) kegiatan industri yang membuang residu zat kimia hasil proses kegiatan yang dilakukan (Aina, Endah, \& Kaswinarni, 2016).

Darmono (2001) menyebutkan bahwa pencemaran yang dapat terjadi di sungai antara lain pencemaran oleh mikroorganisme berbagai kuman penyebab penyakit pada makhluk hidup seperti bakteri, virus, protozoa dan parasit sering mencemari air. Limbah organik menyebabkan kurangnya oksigen terlarut, Pencemaran bahan kimia inorganik seperti asam, garam dan bahan toksik logam seperti $\mathrm{Pb}, \mathrm{Cd}, \mathrm{Hg}$ dalam kadar yang tinggi dapat menyebabkan air tidak enak untuk diminum dan sedimen serta bahan tersuspensi seperti pasir, lumpur, tanah, dan bahan kimia inorganik menjadi bentuk bahan tersuspensi di dalam air, sehingga bahan tersebut menjadi penyebab polusi tertinggi di dalam air.

Semakin bertambahnya jumlah penduduk dan tingginya kegiatan pembangunan di Kota Palembang mengakibatkan semakin meningkatnya kegiatan industri, kegiatan permukiman, dan kegiatan lainnya yang menjadikan peningkatan terhadap jumlah limbah yang dihasilkan setiap harinya. Tinggginya jumlah limbah yang dihasilkan dari proses industri dan proses kegiatan domestik tidak disertai dengan pengelolaan terhadap limbah yang ada sehingga sungai dijadikan salah satu tempat yang digunakan sebagai tempat pembuangan limbah baik limbah industri, limbah organik maupun limbah anorganik. Dari proses tersebut membuat kondisi perairan sungai Musi semakin hari semakin memburuk.

Kondisi Sungai Musi saat ini telah masuk dalam kategori tercemar berat. Hal itu sangat berdampak terhadap aktivitas masyarakat yang dominan masih menggunakan sungai untuk keperluan sehari-hari (Darmono, 2001). Jika dipersentasekan, Sungai Musi tersebut telah tercemar berat hingga 50 persen. Ini terungkap berdasarkan pantauan yang dilakukan oleh Badan Lingkungan Hidup dan Pertanahan Provinsi Sumatera Selatan di tahun 2016. Kemudian Badan Lingkungan Hidup (BLH) Sumatera Selatan menyebut Sungai Musi tercemar limbah industri dan limbah domestik atau hasil pembuangan manusia. Meski demikian, air Sungai Musi masih bisa dimanfaatkan sebagai bahan baku air minum.

\section{Metode}

Penelitian ini merupakan penelitian deskriptif dengan pendekatan kuantitatif dan kualitatif. Penelitian deskriptif dengan pendekatan kuantitatif bertujuan untuk mendeskripsikan kualitas air Sungai Musi. Penelitian ini juga didukung dengan datadata kualitatif untuk memberikan analisis hubungan mengenai aktivitas yang dapat menimbulkan pencemaran air di Sungai Musi dan memberikan solusi terhadap 
penanganan pengendalian pencemaran. Metode yang digunakan dalam penelitian ini adalah metode studi kasus dengan pendekatan survai. Metode studi kasus merupakan metode yang digunakan untuk melihat secara intensif terhadap peristiwa yang akan diselidiki. Selain itu, metode survei digunakan merupakan metode dimana segala aspek harus diamati dengan seksama (Arikunto, 2009), sedangkan hasil analisis datanya hanya berlaku untuk tempat dan jangka waktu tertentu. Bahan dan materi yang dikumpulkan dalam penelitian ini meliputi data primer dan data Sekunder. Data primer diperoleh dari hasil penelitian di lapangan dan hasil analisis laboratorium meliputi konsentrasi TDS, TSS, pH, Besi, Timbal (Pb), Ammoniak (NH3-N) Phosphate (PO4-P), DO, COD, BOD, dan konsentrasi Colyform Total.

\section{Hasil Dan Pembahasan}

\section{Fisiografis Sungai Musi}

Palembang merupakan ibukota Provinsi Sumatera Selatan dan sekaligus sebagai kota terbesar serta pusat kegiatan sosial ekonomi di wilayah Sumatera Selatan. Luas wilayah Kota Palembang adalah sebesar 400,61 km2 atau 40.061 $\mathrm{Ha}$.

Kenampakan dari segi hidrologi, Kota Palembang terbelah oleh Sungai Musi menjadi 2 (dua) wilayah besar yaitu Seberang Ulu dan Seberang Ilir. Sungai Musi merupakan sungai terbesar dengan lebar rata-rata 504 meter. Ketiga sungai besar lainnya adalah Sungai Komering, Sungai Ogan, dan Sungai Keramasan yang terletak di Seberang Ulu. Disamping sungai-sungai besar tersebut terdapat sungai-sungai kecil lainnya yang terletak di Seberang llir yang berfungsi sebagai drainase perkotaan.

Sungai Musi adalah sungai yang terletak di Provinsi Sumatera Selatan memiliki panjang $750 \mathrm{~km}$ dan merupakan sungai terpanjang di Pulau Sumatera. Sungai Musi yang melewati administrasi Kota Palembang membelah Kota Palembang menjadi dua kawasan, yaitu
Seberang Ilir di bagian utara dan Seberang Ulu di bagian selatan. Sungai Musi memiliki peranan penting bagi kehidupan masyarakat, oleh karena itu kelestarian dan kelangsungan fungsinya harus dijaga dengan mengamankan daerah di sekitarnya. Kenyataan di lapangan, sungai tersebut sudah mulai terganggu fungsi dan tatanannya akibat aktivitas yang berkembang di sekitarnya (intervensi bangunan dan sampah yang dibuang ke badan sungai) dan mengakibatkan terganggunya ekosistim sungai, menurunnya kualitas air sungai, serta melimpasnya air di kawasan sempadan sungai. Untuk mencegah lebih besarnya kerugian akibat dari kerusakan sungai tersebut perlu dilakukan penataan daerah sempadan sungai dengan kegiatan konservasi, pendayagunaan, pengendalian atas sumber daya yang ada pada sungai.

Segmen hulu dengan ekosistem hutan lindung telah mengalami perubahan tata guna lahan sampai di hilir yang sarat akan pemukiman dan industri seperti pengilangan minyak, pabrik pupuk, pengolahan karet alam, kayu lapis dan lain-lain sehingga berpotensi menyebabkan degradasi kualitas lingkungan perairan sungai. Di bagian hilir inipun perairan Musi merupakan sumber air, tidak hanya bagi penduduk di sepanjang sungai, tetapi juga merupakan sumber air sekaligu tempat membuang limbah cair oleh induslri sehingga berdampak kepada perurunan kualitas perairan Musi. Beragamnya kegiatan manusia di sepanjang Sungai Musi ini berdampak terhadap kualitas air Sungai Musi.

\section{Analisis Fisika dan Kimia di Sungai Musi}

Kualitas fisik dan kimia air Sungai Musi yang diukur dalam penelitian ini meliputi TSS, TDS, Besi (Fe), pH, Amonia Total, Timbal (Pb), Pospat, COD, BOD, dan DO. Hasil Uji Laboratorium kualitas fisika dan kimia air sungai musi seperti terlihat pada Tabel 1. dan Tabel 2. 
Tabel 1. Hasil Uji Laboratorium Unsur Fisika

\begin{tabular}{|c|c|c|c|c|c|c|c|c|}
\hline Unsur & S 1 & S 2 & S 3 & S 4 & S 5 & S 6 & Maks & Metode \\
\hline TDS/TS & 36,4 & 33,3 & 33,4 & $\overline{33,4}$ & 32,8 & 31,4 & 1000 & Potensiometri \\
\hline TSS & 0,2 & 0,3 & 0,3 & 0,2 & 0,2 & 0,3 & & Gravimetri \\
\hline
\end{tabular}

Sumber: Analisis Data Primer, 2019

Tabel 2. Hasil Uji Laboratorium Unsur Kimia

\begin{tabular}{lrrrrrrll}
\hline \multicolumn{1}{c}{ Unsur } & S 1 & S 2 & S 3 & S 4 & S 5 & S 6 & Maks & Metode \\
\hline Besik & 453, & 142,12 & 532,59 & 447,56 & 288,066 & 395,12 & 1000 & APHA 3120:2017 \\
PH Air & 054 & 3 & 3 & 1 & & 9 & & \\
& 6,99 & 6,64 & 6,53 & 6,4 & 6,42 & 6,43 & $6,5-8,5$ & SNI 06-6989 11- \\
Amonia & 1,31 & 0,73 & 0,73 & 0,62 & 0,43 & 0,42 & & Nessler \\
Timbal & $<2,821$ & $<2,821$ & $<2,821$ & $<2,821$ & $<2,821$ & $<2,821$ & 50 & APHA 3120 : 2017 \\
Posfat & $<0,01$ & 0,042 & 0,06 & 0,04 & 0,21 & 0,029 & & SNI 6989.31-2004 \\
COD & 18 & 30 & 97 & 26 & 25 & 34 & Spectrophotometri \\
BOD & 16 & 2 & 12 & 17 & 14 & 21 & & Manometri \\
DO & 7,49 & 7,37 & 7,43 & 7,6 & 7,55 & 7,64 & & Potensiometri \\
\hline
\end{tabular}

Sumber: Analisis Data Primer, 2019

\section{Total Suspended Solid (TSS)}

Total Suspended Solid (TSS) atau padatan tersuspensi terdiri atas partikel partikel yang memiliki ukuran dan berat lebih kecil dari pada sedimen, seperti tanah liat,sel-sel mikroorganisme, bahan bahan organik tertentu dan lain - lain (Edward, 2014). Adanya kadar Total Suspended Solid menjadi suatu ciri terjadinya proses erosi yang dapat meningkatkan tingkat kekeruhan pada suatu perairan.

Hasil uji laboratorium dapat disimpulkan bahwa konsentrasi padatan tersuspensi di Sungai Musi berkisar antara 0,2 - 0,3 Mg/l hal ini masih dapat ditoleransi untuk kualitas air sungai. Dari hulu ke hilir terlihat konsentrasi TSS semakin meningkat yang kemudian sedikit menurun pada bagian hilir sungai.

\section{Total Dissolved Solid (TDS)}

Total Dissolved Solid (TDS) atau total padatan terlarut adalah padatan padatan padatan yang berukuran lebih kecil daripada padatan tersuspensi. Padatan ini terdiri dari senyawa-senyawa organik dan anorganik yang larut air, mineral dan garam-garamnya, misalnya air buangan industri yang mengadung mineral - mineral tertentu serta air buangan rumah tangga dan industri yang mengandung sabun, deterjen dan surfaktan yang larut dalam air (Edward, 2014).

Berdasarkan hasil survey langsung terhadap tingkat kekeruhan sungai musi serta hasil uji sampel di laboratorium didapatkan konsentrasi total padatan tersuspensi pada air sungai musi berkisar antara 31,4-36,4 Mg/L.

\section{Besi (Fe)}

Logam besi disamping karena kelimpahannya yang cukup banyak di alam, adalah merupakan salah satu logam yang paling reaktif dan paling vital bagi mahluk hidup. Dalam sistem peredaran darah, dengan kadar tertentu besi berada dalam sel darah merah (Erythrocyte) dan bertugas untuk mengikat Oksigen $\left(\mathrm{O}_{2}\right)$ yang sangat penting bagi proses pembakaran yang terjadi dalam sel-sel tubuh.

Kegiatan lapangan dan uji laboratorium menunjukkan konsentrasi besi pada 6 titik pengambilan sampel air diperoleh data konsentrasi besi berkisar antara $288 \mathrm{mg} / \mathrm{l}$ sampai dengan $453 \mathrm{mg} / \mathrm{l}$. Konsentrasi unsur besi tertinggi berada pada lokasi sampel 1 yang merupakan bagian hilir Sungai Musi. Daerah ini berada di bagian paling hilir sungai sehingga seluruh konsentrasi zat 
pencemar dari hulu akan ditransfer kebagian hilir sungai. Dengan demikian dapat disimpulkan bahwa tingginya konsentrasi besi di daerah hilir merupakan dampak yang ditimbulkan oleh hasil kegiatan masyarakat dari bagian hulu sungai dan bagian tengah Sungai Musi di Kota Palembang.

\section{pH}

$\mathrm{pH}$ air normal berkisar antara 6,5 7,5 yang memenuhi syarat untuk suatu kehidupan. $\mathrm{pH}$ bersifat asam jika nilainya di bawah $\mathrm{pH}$ normal, sedangkan jika nilai
$\mathrm{pH}$ di atas normal maka bersifat basa. Air limbah dan buangan industri dapat mempengaruhi $\mathrm{pH}$ air yang akhirnya akan berdampak pada kehidupan organisme di dalam air (Darmono, 2001). Berdasarkan hasil pengukuran $\mathrm{pH}$ air di Sungai Musi pada waktu penelitian dan dilanjutkan dengan uji laboratorium diketahui konsentrasi $\mathrm{pH}$ air sungai berkisar antara 6,4 sampai dengan 6,9. Konsentrasi $\mathrm{pH}$ pada perairan Sungai Musi disajikan dalam Gambar 1.

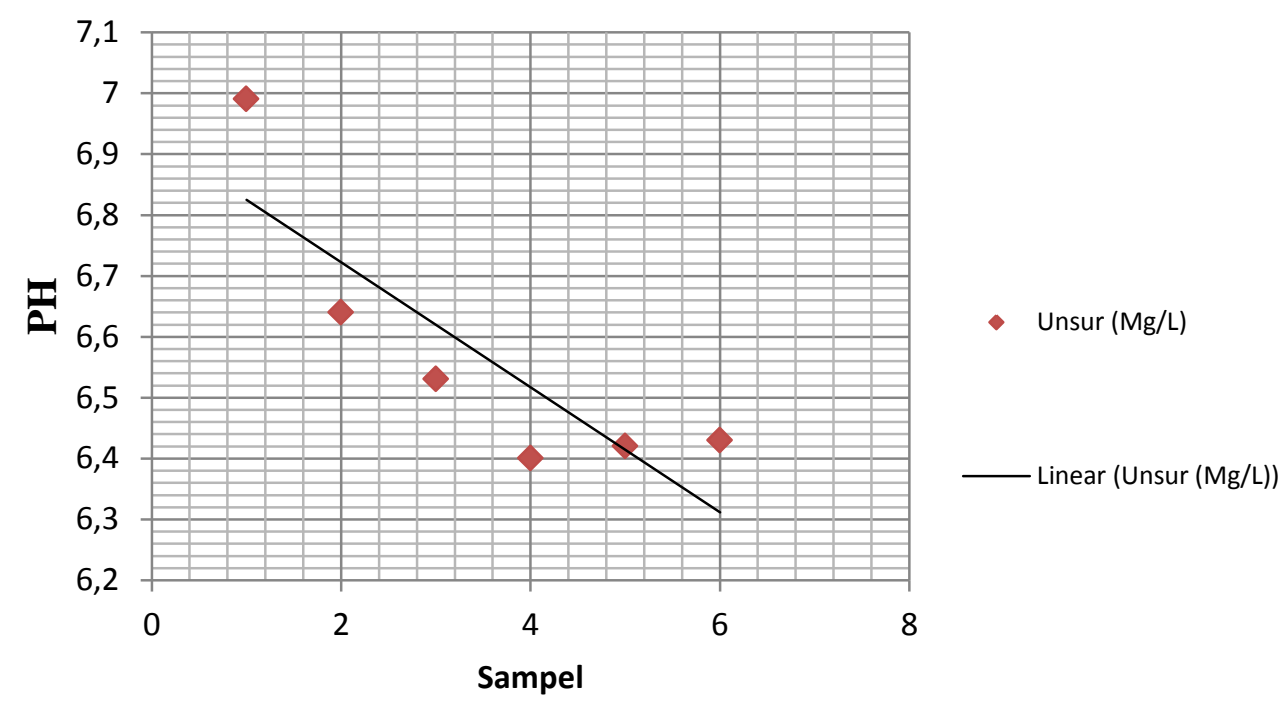

Gambar 1. Konsentrasi pH

(Sumber: Analisis Data Primer, 2019)

Unsur Posfat

Kandungan fosfor merupakan kandungan yang sangat penting bagi kehidupan ekosistem dalam perairan. Zat - zat organik seperti protein mengandung gugus fosfor misalkan ATP, yang terdapat dalam sel mahluk hidup dan berperan penting dalam penyedia energi. Ekosistem perairan, fosfor tersedia dalam tiga bentuk yaitu senyawa fosfor organic, seperti ortofosfat, senyawa organik dalam protoplasma dan sebagai senyawa organic terlarut yang terbentuk dari proses penguraian tubuh organisme (Setyaningsih, Sriyono, \& Benardi, 2018). Keberadaan senyawa fosfor dalam ekosistem perairan adalah sangat penting terutama dalam pembentukan senyawa protein dan metabolisme bagi organisme. Fosfor juga juga berperan dalam transfer energi di dalam sel misalnya adenosine triphosphate (ATP) dan adenosine diphosphate (ADP). Ortofosfat yang merupakan produk ionisasi dari asam ortofosfat adalah bentuk yang paling sederhana di perairan (Budiarta, 2014). 
Uji laboratorium menunjukkan bahwa konsentrasi fosfat pada air Sungai Musi di Kota Palembang berkisar antara $<0,01$ sampai dengan $0,06 \mathrm{mg} / \mathrm{l}$. Konsentrasi fosfat tertinggi berada pada sampel 3 yang berada di sekitar pelabuhan Boom Baru Kota Palembang.

\section{Amoniak Total}

Peraturan Pemerintah No. 82 Tahun 2001 tentang Pengelolaan Kualitas Air dan Pengendalian Pencemaran Air, baku mutu amonia untuk sungai kelas satu adalah sebesar $0,5 \mathrm{mg} \mathrm{NH} 3-\mathrm{N} /$ liter. Menurut Effendi (2003) kadar amonia dalam perairan alami biasanya kurang dari $0,1 \mathrm{mg} \mathrm{NH} 3 /$ liter. Konsentrasi amonia yang tinggi dalam badan sungai mengindikasikan adanya pencemaran yang salah satunya disebabkan oleh buangan air limbah domestik baik segar (tidak terolah) maupun telah terolah.

Dari hasil penelitian dan uji laboratorium dapat diketahui konsentrasi Amoniak total pada perairan Sungai Musi berkisar antara 0,42 $\mathrm{mg} / \mathrm{l}$ sampai dengan 1,31 mg/l. Konsentrasi unsur Amoniak total pada perairan Sungai Musi tertinggi berada pada titik sampel 1 yang berada pada hilir sungai musi yaitu di wilayah Pelabuhan Dermaga Sungai Lais.

\section{Timbal $(\mathbf{P b})$}

Timbal atau $\mathrm{Pb}$ merupakan salah satu pencemar yang dipermasalahkan karena bersifat sangat toksik dan tergolong dari buangan yang sangat beracun berbahaya. Timbal $(\mathrm{Pb})$ termasuk dalam kelompok logam yang beracun dan berbahaya bagi kehidupan makhluk hidup. Limbah Timbal $(\mathrm{Pb})$ dapat masuk ke badan perairan secara alamiah yakni dengan pengkristalan $\mathrm{Pb}$ di udara dengan bantuan air hujan.Penggunaan $\mathrm{Pb}$ dalam skala yang besar dapat mengakibatkan polusi baik di daratan maupun perairan. Logam $\mathrm{Pb}$ yang masuk ke dalam perairan sebagai dampak dari aktivitas manusia dapat membentuk air buangan atau limbah dan selanjutnya akan mengalami pegendapan yang dikenal dengan istilah sedimen. Uji laboratorium pada sampel air Sungai Musi diperoleh data bahwa konsentrasi Timbal $(\mathrm{Pb})$ pada Sungai Musi dari hulu sungai sapai hilir Sungai Musi yaitu $<2,821$ dengan ambang batas yang disarankan yaitu $50 \mathrm{mg} / \mathrm{l}$.

\section{Chemical Oxygen Demand (COD)}

Tingkat pencemaran pada perairan dapat dianalisis juga berdasarkan kadar COD (Chemical Oxygen Demand). Hasil analisa COD merupakan parameter yang menunjukkan banyaknya oksigen yang digunakan untuk oksidasi secara kimiawi. COD atau Chemical Oxygen Demand menurut (Boyd, 1990) merupakan jumlah oksigen yang diperlukan untuk mengurai seluruh bahan organik yang terkandung dalam air.

Berdasarkan kegiatan lapangan dan uji laboratorium terhadap air Sungai Musi pada 6 sampel air diperoleh konsentrasi COD berkisar antara $18 \mathrm{mg} / \mathrm{l}$ sampai dengan $97 \mathrm{mg} / \mathrm{l}$. Konsentrasi COD tertinggi berada pada titik sampel 3 yang berada dibagian tengah Sungai Musi Kota Palembang.

\section{Biological Oxygen Demand (BOD)}

Kadar BOD merupakan salah satu parameter yang dapat dijadikan tolak ukur beban pencemaran suatu perairan. Pemeriksaan BOD sangat penting untuk menelusuri aliran pencemaran karena dapat menentukan beban pencemaran akibat air buangan dan mendesain sistem pembuangan secara biologis bagi air tercemar (Agnes \& Azizah, 2005).

Hasil penelitian dan uji laboratorium terhadap unsure BOD pada perairan Sungai Musi berkisar antara 2 $\mathrm{mg} / \mathrm{l}$ sampai dengan $21 \mathrm{mg} / \mathrm{l}$. Konsentrasi nilai $B O D$ tertinggi berada pada titik sampel 6 dan konsentrasi nilai terendah berada pada titik sampel 2 . 


\section{Oksigen Terlarut (DO)}

Adapun kadar oksigen terlarut dalam air tergantung pada beberapa proses diantaranya pergerakan massa air, percampuran, aktivitas fotosintesis dan respirasi serta masukan limbah ke badan air (Effendi, 2003).

Hasil pengukuran konsentrasi oksigen terlarut (DO) air Sungai Musi disajikan pada Tabel berikut. Proses dekomposisi bahan organik dan oksidasi bahan anorganik dapat mempengaruhi jumlah oksigen terlarut dalam suatu perairan.
Hasil penelitian dan uji laboratorium pada perairan Sungai Musi Kota Palembang dapat diketahui bahwa konsentrasi DO berkisar antara 7,37 mg/l sampai dengan 7,64 mg/l. Konsentrasi DO tertinggi berada pada titik sampel 4 yang berada disekitar Pasar 16 llir dan Jembatan Ampera. Tingginnya konsentrasi DO pada perairan Sungai Musi berasal dari proses dekomposisi bahan organik yang berasal dari sampah organik rumah tangga. Kondisi Kimia dengan kadar maksimum yang disarankan $0 \mathrm{mg} / \mathrm{l}$ disajikan dalam Gambar 2.

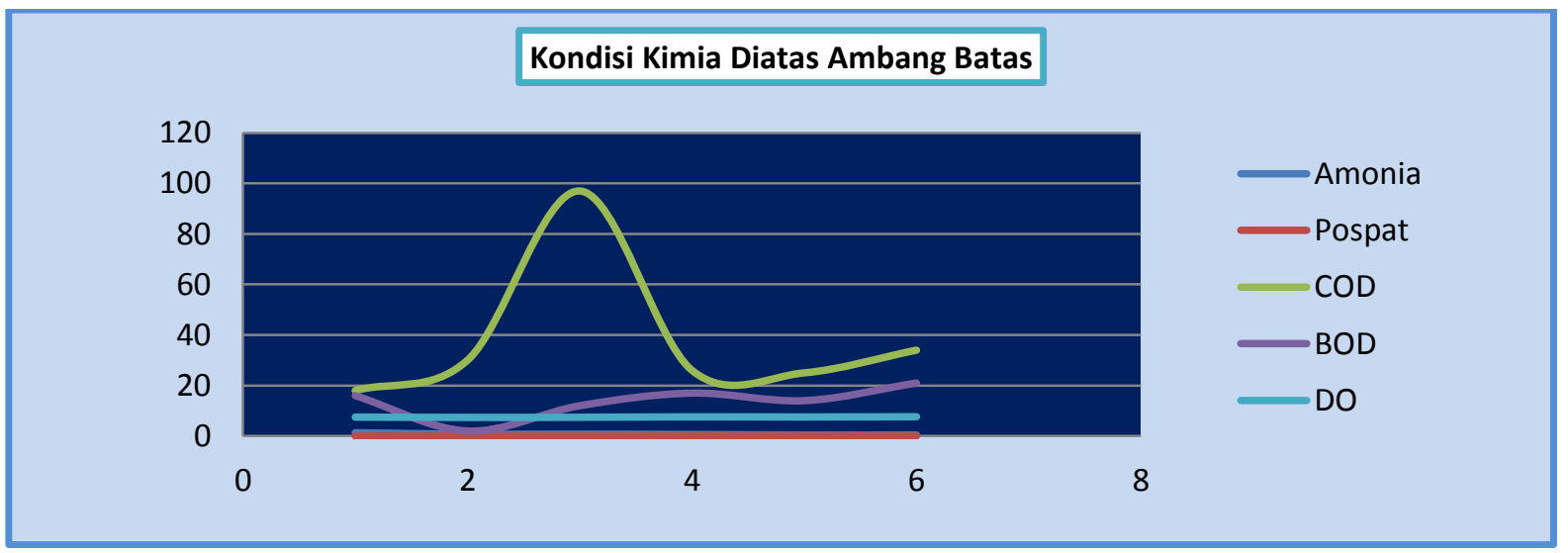

Gambar 2. Kondisi Kimia Sungai Musi

(Sumber: Analisis Data Primer, 2019)

\section{Kondisi Biologi}

Total Coliform merupakan bakteri yang biasanya ditemukan di lingkungan air dan tanah yang mana telah dipengaruhi oleh air permukaan serta limbah yang berasal dari buangan kotoran manusia dan hewan. Pengukuran kualitas air parameter mikrobiologi di Sungai Musi meliputi total coliform. Pengujian kualitas air untuk total coliform dan fecal coliform menggunakan metode Most Probable Number (MPN) yaitu uji yang mendeteksi sifat fermentatif coliform dalam sampel yang ditunjukkan dengan terbentuknya gas atau gelembung dalam tabung durham yang dihitung sebagai tabung positif. Pengujian bakteri E.coli dilakukan dengan metode isolasi bakteri menggunakan media selektif yaitu Chromocult Coliform Agar yang mendeteksi bakteri E.coli berdasarkan warna pada koloni yang terbentuk yaitu ditandai dengan warna biru tua.

Konsentrasi bakteri coliform berada pada konsentrasi lebih dari 2400 MPN Coliform $/ 100 \mathrm{ml}$. Tingginya konsentrasi coliform hampir sama antara bagian hulu Sungai Musi sampai dengan bagian hilir Sungai Musi Kota Palembang.

Tabel 3. Konsentrasi Unsur Bakteri Coliform

\begin{tabular}{llll}
\hline No & Sampel & Konsentrasi & Kategori \\
\hline 1 & Hilir & $>2400$ & Tidak Baik \\
2 & Tengah & $>2400$ & Tidak Baik \\
3 & Hulu & $>2400$ & Tidak Baik \\
\hline
\end{tabular}

Sumber: Analisis Data Primer, 2019 


\section{Faktor Determinan Pencemaran Sungai}

Dari hasil penelitian dilapangan melalui pengamatan, survey dan hasil uji laboratorium dapat disimpulkan bahwa pencemaran yang terjadi pada perairan Sungai bersumber dari faktor organik yang berasal dari sampah rumahtangga dan limbah industri.

\section{Faktor Sampah Rumah Tangga}

Karakteristik pencemaran di perairan Sungai Musi sebagian besar didominasi oleh dekomposisi organik pada air sungai menunjukan bahwa faktor sampah rumahtangga merupakan faktor determinan utama yang mencemari Sungai Musi. Tingginya kadar organik dalam perairan Sungai Musi dapat dilihat dari konsentrasi kadar TDS, Amoniak Total, Besi, Timbal, COD, BOD, DO dan konsentrasi bakteri colyform yang berada diatas ambang batas baik dari sungai bagian hulu maupun bagian hilir.

Kadar Organik limbah sebagian besar berasal dari air bekas cucian, air dari dapur, air kamar mandi, dan air limpahan dari tangki septik dibuang ke saluran drainase bergabung dengan air hujan mengalir ketempat yang lebih rendah melalui saluran alami dan saluran buatan. Jaringan air limbah rumah tangga mengikuti saluran air kota yang tersedia. Pengolahan air limbah terjadi secara alami ketika air mengalir. Air limbah rumah tangga di Kota Palembang sebagian besar berakhir di Sungai Musi yang merupakan sungai terbesar di Provinsi Sumatera Selatan.

Pengolahan air limbah domestik Kota Palembang umumnya menggunakan sistem sanitasi setempat (on site system) dengan menggunakan jamban, baik yang dikelola secara individu maupun secara komunal, yang dilengkapi dengan tangki septik atau cubluk. Disamping itu dengan adanya sungai-sungai yang mengalir melalui Kota Palembang dapat dimanfaatkan sebagai tempat buangan air limbah.

\section{Faktor Industri}

Limbah industri mengandung zatzat yang berbahaya yang dapat mengancam kehidupan manusia. Sifat dari limbah industri adalah mengandung racun, bersuhu tinggi, menimbulkan iritasi, menimbulkan bau, mudah terbakar, dan bereaksi pada jaringan tubuh, dan termasuk dalam kategori bahan-bahan berbahaya (B-3). Dampak berbahaya terhadap kesehatan dapat berupa gangguan fungsi organ tubuh atau gangguan proses biokimia yang ditandai dengan kerusakan jaringan, kelainan fungsi organ, gangguan terhadap sistem enzim dan endoktrin.

Pengelolaan limbah cair industri di Kota Palembang masih kurang mendapat perhatian. Limbah cair industri terutama industri besar sebagian diolah langsung oleh masing-masing industri dimana sistemnya sangat bergantung pada jenis limbah yang dihasilkan, namun demikian ada beberapa industri yang langsung membuang ke badan air. Hal ini sangat mengkhawatirkan karena berpotensi sangat besar untuk mencemari lingkungan. Pemerintah Kota secara berkala telah melakukan pemantauan terhadap pengolahan limbah industri tersebut, yang dilakukan oleh Badan Lingkungan Hidup (BLH) Kota Palembang.

\section{Pencemaran Sungai Musi}

Sungai Musi merupakan
sumberdaya alam yang menjadi salah satu jalur utama perdagangan dan pemasok air terbesar bagi penduduk Sumatera Selatan. Perusahaan Daerah Air Minum (PDAM) Tirta Musi Palembang memanfaatkan Sungai Musi sebagai sumber bahan baku air untuk memenuhi kebutuhan air bersih penduduk. Pencemaran yang terjadi di aliran sungai Musi menjadi hal yang perlu dipantau dan 
dijaga karena memiliki dampak terhadap seluruh aktivitas yang ada di sekitarnyanya. Terdapat beberapa faktor penyebab sungai Musi tercemar seperti alih fungsi hutan alam dan lahan alami.

Penyebab utamanya adalah alih fungsi hutan alam dan lahan alami (rawa) oleh berbagai aktivitas pembalakan liar dan industri. Lahan kritis pada wilayah DAS di Sumsel terbagi dalam empat kategori diantaranya kategori agak kritis seluas 1,7 juta ha, kategori kritis 3,5 juta ha, potensial kritis 1,5 juta ha dan sangat kritis 784 ha. Proyek perkebunan skala besar seperti kelapa sawit ataupun Hutan Tanaman Industri ( $\mathrm{HTI}$ ) hingga saat ini semakin berpengaruh dalam menghancurkan wilayah DAS, hutan gambut dan kawasan suaka alam lainnya.

Pada bagian hulu aliran Sungai Musi berlokasi industri pupuk urea, limbah cair hasil proses pengolahan dapat saja dibuang ke perairan Sungai Musi, sehingga mempengaruhi kualitas perairan. Selain itu, terdapat pula wilayah permukiman padat di Kota Palembang dengan aliran Sungai Musi yang melalui pemukiman tersebut, dimana aktivitas warga di perairan sungai masih cukup tinggi. Tingginya aktivitas di perairan sungai tentunya juga dapat memberikan pengaruh terhadap kualitas air sungai, bahkan dapat menyebabkan pencemaran air sungai.

Pencemaran di hulu juga diakibatkan kebakaran hutan dan kegiatan industri yang membuang limbah produksi yang sebenarnya belum memenuhi baku mutu untuk dilepas secara langsung ke sungai. Sementara, di bagian hilir selain disebabkan rumahtangga yang membuang sisa-sisa makanan, sampah, kotoran atau tinja baik manusia maupun hewan yang mengandung bakteri Fecal coli ke sungai, pencemaran juga diakibatkan oleh kegiatan perdagangan, domestik, maupun transportasi sungai, dan terutama oleh aktivitas industri.
Pencemaran ini membuat kualitas air semakin menurun dan biaya produksi untuk pengolahan air semakin tinggi. Pencemaran ini juga berpengaruh terhadap penurunan ekonomi di daerah Sungai Musi karena banyaknya warga yang menggantungkan diri dari pemanfaatan Sungai Musi seperti objek wisata, transportasi, bekerja sebagai nelayan, dan banyaknya tempat-tempat makan dan hotel di pinggiran sungai.

Kegiatan industri dapat memberi dampak berupa dampak positif maupun dampak negatif. Banyak industri skala besar yang secara geografis berbatasan langsung dengan Sungai Musi dan sangat rentan dengan masalah lingkungan. Salah satu masalah yang timbul yaitu pencemaran limbah, sementara Sungai Musi merupakan salah satu sungai yang selama ini dimanfaatkan warga sekitar untuk memenuhi kebutuhan air seharihari.

Pada kegiatan operasional produksinya industri menghasilkan limbah pencemaran yang mengandung ammonia dan sangat beracun bagi biota air, terutama ikan dan pencemaran tersebut berdampak negatif bagi masyarakat. Limbah cair adalah salah satu limbah yang dibuang industri ke Sungai Musi, yang mengandung bahan-bahan organik maupun anorganik. Banyak warga yang mengeluh setiap kali pabrik mengeluarkan limbah, karena menimbulkan bau yang tidak sedap, sesak napas dan kadang mengakibatkan mual jika mengkonsumsi air yang diambil dari Sungai Musi.

Mulai hulu ke hilir terlihat konsentrasi TSS semakin meningkat yang kemudian sedikit menurun pada bagian hilir sungai. Tingginya nilai konsentrasi TSS dapat disebabkan oleh banyaknya padatan yang berasal dari limbah domestik serta industri di sekitar Sungai Musi sehingga mempengaruhi kejernihan air sungai tersebut. Rendahnya konsentrasi TSS di beberapa site dapat 
dikarenakan kondisi lingkungan di sekitar sungai yang masih terdapat lahan hijau serta memperoleh tambahan oksigen dari proses fotosintesis tanaman air.

$$
\text { Konsentrasi total padatan }
$$

tersuspensi dengan kandungan terbesar berada pada sampel 1 yang berada dibagian hilir Sungai Musi. Daerah ini sebagian besar penggunaannya berupa kawasan industri dan permukiman padat penduduk. Dari hasil uji laboratorium dapat disimpulkan bahwa kandungan total padatan terlarut pada air sungai musi masih berada pada batas normal dimana batas maksimal yang disarankan yaitu $1000 \mathrm{mg} / \mathrm{l}$.

Konsentrasi $\mathrm{pH}$ air sungai berkisar antara 6,4 sampai dengan 6,9 konsentrasi kadar $\mathrm{pH}$ terendah berada pada sampel 4 , sampel 4 berada pada tengah Sungai Musi yaitu disekitar Pasar 16 llir dan Jembatan Ampera. Penggunaan lahan didaerah ini sebagian besar merupakan pusat perbelanjaan, pusat kegiatan dan pusat perkantoran. Sedangkan parameter $\mathrm{pH}$ tertinggi berada pada sampel 1 yang merupakan titik sampel yang berada didaerah hilir Sungai Musi Kota Palembang. Daerah ini sebagian besar merupakan daerah limpahan zat pencemar yang berasal dari hulu ke hilir. Dari konsentrasi nilai $\mathrm{pH}$ pada daerah penelitian dapat disimpulkan bahwa kondisi pH air Sungai Musi masih normal dan berada pada ambang batas yang diperbolehkan bagi air sungai.

Konsentrasi besi berkisar antara $288 \mathrm{mg} / \mathrm{l}$ sampai dengan $453 \mathrm{mg} / \mathrm{l}$, konsentrasi unsur besi tertinggi berada pada lokasi sampel 1 yang merupakan bagian hilir Sungai Musi. Daerah ini berada dibagian paling hilir sungai sehingga seluruh konsentrasi zat pencemar dari hulu akan ditranfer kebagian hilir sungai. Dengan demikian dapat disimpulkan bahwa tingginya konsentrasi besi didaerah hilir merupakan dampak yang ditimbulkan oleh hasil kegiatan masyarakat dari bagian hulu sungai dan bagian tengah Sungai Musi di Kota Palembang.

Konsentrasi fosfat pada air Sungai Musi di Kota Palembang berkisar antara $<0,01$ sampai dengan 0,06 $\mathrm{mg} / \mathrm{l}$. Konsentrasi fosfat tertinggi berada pada sampel 3 yang berada disekitar pelabuhan Boom Baru Kota Palembang. Kandungan posfat yang terdapat pada perairan Sungai Musi merupakan unsure fosfat yang berasal dari reaksi fosfor organic dari hasil proses kegiatan domestic rumahtangga. Semakin tingginya kegiatan domestic disuatu wilayah seperti wilayah perkotaan akan meningkatkan jumlah sisa organic yang akan dibuang ke sungai, oleh sebab itu reaksi organic fosfor pada badan perairan akan semakin meningkat.

Konsentrasi unsur Amoniak total pada perairan Sungai Musi tertinggi berada pada titik sampel 1 yang berada pada hilir sungai musi yaitu di wilayah Pelabuhan Dermaga Sungai Lais. Sedangkan konsentrasi amoniak terendah berada pada titik sampel 6 yang berada di daerah Pulokerto Kecamatan Gandus Kota Palembang. Sesuai dengan peraturan mengenai kandungan amoniak pada air sungai dapat disimpulkan bahwa konsentrasi amoniak pada hilir sungai sudah berada pada kondisi yang kurang baik atau diatas ambang batas yang disarankan dimana ambang batas untuk kandungan amoniak pada perairan yaitu 0 $\mathrm{mg} / \mathrm{l}$. Tingginya konsentrasi amoniak total pada perairan terutama sungai akan sangat berdampak negative bagi kehidupan biota didalam air. Tingginya konsentrasi aminiak akan bersifat meracun pada biota seperti ikan, udang dan kerang sehingga pada konsentrasi yang diatas ambang batas akan membuat biota tersebut mengalami lemas dan menimbulkan kematian.

Konsentrasi Timbal (Pb) pada Sungai Musi dari hulu sungai sapai hilir Sungai Musi yaitu $<2,821$ dengan ambang 
batas yang disarankan yaitu $50 \mathrm{mg} / \mathrm{l}$. Dari data tersebut dapat disimpulkan bahwa kondisi unsure Timbal dalam perairan Sungai Musi masih berada pada ambang normal sesuai dengan baku mutu yang disarankan.

Konsentrasi DO berkisar antara $7,37 \mathrm{mg} / \mathrm{l}$ sampai dengan 7,64 mg/l. Konsentrasi DO tertinggi berada pada titik sampel 4 yang berada disekitar Pasar 16 llir dan Jembatan Ampera. Tingginnya konsentrasi DO pada perairan Sungai Musi berasal dari proses dekomposisi bahan organik yang berasal dari sampah organik rumahtangga. Menurunnnya kandungan oksigen terlarut dari hulu ke hilir di Sungai Musi mengindikasikan terjadinya peningkatan proses dekomposisi bahan organik dan oksidasi bahan anorganik akibat meningkatnya buangan limbah di sekitar sungai tersebut. Pada sampel yang termasuk bagian hulu terlihat bahwa konsentrasi DO cenderung lebih tinggi, hal ini dikarenakan lokasi tersebut masih didominasi oleh lahan hijau dan belum banyak aktivitas manusia yang menghasilkan limbah yang dapat menurunkan konsentrasi oksigen terlarut.

Konsentrasi COD berkisar antara

$18 \mathrm{mg} / \mathrm{l}$ sampai dengan $97 \mathrm{mg} / \mathrm{l}$. Konsentrasi COD tertinggi berada pada titik sampel 3 yang berada dibagian tengah Sungai Musi Kota Palembang. Daerah disekitar sampel penelitian merupakan daerah yang digunakan sebagai permukiman padat penduduk serta pergudangan. Selain itu daerah ini juga terdapat industri serta pelabuhan. Tingginyaa konsentrasi COD pada titik sampel 3 disebabkan karena transfer sedimaen dan limbah organik rumahtangga yang berasal dari tengah dan hulu Sungai Musi Kota Palembang. Padatnya konsentrasi penduduk disekitar bagian tengah sungai menyebebkan banya sampah arganik rumahtangga yang masuk kedalam sungai sehingga membutuhkan oksidasi yang maksimal.
Dengan demikian dapat disimpulkan bahwa konsentrasi COD pada perairan Sungai Musi berada diatas ambang batas normal yang disyaratkan.

Konsentrasi unsur BOD pada perairan Sungai Musi berkisar antara 2 $\mathrm{mg} / \mathrm{l}$ sampai dengan $21 \mathrm{mg} / \mathrm{l}$. Konsentrasi nilai $B O D$ tertinggi berada pada titik sampel 6 dan konsentrasi nilai terendah berada pada titik sampel 2 . Tingginya konsentrasi BOD menjadi penenda bahwa kondisi perairan sudah mulai mengalami pencemaran.

Secara keseluruhan konsentrasi bakteri Coliform di Sungai Musi sudah dalam kategori yang sangat tidak baik, hal ini dilihat dari besarnya konsentrasi bakteri dalam air. Konsentrasi bakteri koliform berada pada konsentrasi lebih dari 2400 MPN Coliform $/ 100 \mathrm{ml}$. Tingginya konsentrasi coliform hampir sama antara bagian hulu Sungai Musi sampai dengan bagian hilir Sungai Musi Kota Palembang. Tingginya konsentrasi bakteri coliform berasal dari pembuangan tinja atau kotoran baik yang berasal dari kotoran hewan atau kotoran manusia yang langsung dibuang ke Sungai Musi. Tingginya konsentrasi bakteri coliform tidak dapat disimpulkan berasal dari Pencemaran yang bersumber dari masyarakat yang ada di Kota Palembang dikarenakan sebagian besar ditransfer dari bagian Sungai Musi yang berada di bagian Hulu. Aina et al. (2016) menyatakan air yang tercemar akibat segala aktivitas mengandung jutaan bakteri coliform streptococcus yang berasal dari limbah industri, permukiman, dan air tanah.

Hal ini sesuai dengan penelitian Setianto \& Murjainah (2019) mengenai jumlah bakteri colyform terhadap 18 sampel airtanah dapat diketaui bahwa kandungan bakteri colyform berkisar antara $0-4,5 \mathrm{MPN} / 100 \mathrm{ml}$ airtanah. Tidak hanya itu air yang tercemar termasuk didalamnya terdapat bakteri Kondisi ini dapat disimpulkan bahwa sesuai dengan 
baku mutu yang disarankan pada air untuk kebutuhan airminum baku mutu yang disarankan adalah $0 \mathrm{MPN} / 100 \mathrm{ml}$ artinya pada airminum kandungan bakteri coly harus 0 atau bersih dari bakteri. Dari hasil penelitian masih terdapat beberapa sampel air yang mengandung bakteri coly lebih dari 0 MPN $/ 100 \mathrm{ml}$ hal ini mengindikasikan bahwa kondisi air dari beberapa sumur warga telah mengalami pencemaran.Pencemaran pada airsumur sebagian besar disebabkan oleh kondisi lingkungan yang kurang dikelola dengan baik. Penggunaan airsumur pada daerah penelitian untuk pemenuhan kebutuhan air konsumsi harus melalui proses pengolahan agar airtanah yang dikonsumsi bebas dari kandungan bakteri coly.

Penelitian sebelumnya dapat disimpulkan bahwa sebagian besar pengaruh tingkat pencemaran yang terjadi pada perairan di Sungai Musi disebabkan oleh karena pengelolaan lingkungan yang kurang baik (Aswadi, Riani, Pramudya, \& Kurniawan, 2019; Christanto, Setiawan, Nurkholis, \& Istiqomah, 2018). Pengelolaan lingkungan yang paling berpengaruh pada pencemaran sungai musi diantaranya yaitu pembuangan sampah organik dan non organik langsung ke badan perairan. Kegiatan ini dilakukan oleh masyarakat yang berada dibagian hulu Sungai Musi dan sungai-sungai besar yang bermuara ke Sungai Musi hingga masyarakat yang berada pada bagian tengah Sungai Musi yaitu di daerah Perkotaan. Kondisi ini membuat kondisi peraian Sungai Musi semakin darurat pencemaran dari tahun ke tahun.

Ada dua faktor pencemaran pada Sungai Musi di Kota Palembang, yaitu pencemaran akibat proses dari kegiatan domestik dan penyebab pencemaran yang berasal dari kegiatan industri. Karakteristik pencemaran di perairan Sungai Musi sebagian besar didominasi oleh dekomposisi organik pada air sungai menunjukan bahwa faktor sampah rumahtangga merupakan faktor determinan utama yang mencemari Sungai Musi. Tingginya kadar organik dalam perairan Sungai Musi dapat dilihat dari konsentrasi kadar TDS, Amoniak Total, Besi, Timbal, COD, BOD, DO dan konsentrasi bakteri colyform yang berada diatas ambang batas baik dari sungai bagian hulu maupun bagian hilir.

Pengelolaan limbah cair industri di Kota Palembang masih kurang mendapat perhatian. Limbah cair industri terutama industri besar sebagian diolah langsung oleh masing-masing industri dimana sistemnya sangat bergantung pada jenis limbah yang dihasilkan, namun demikian ada beberapa industri yang langsung membuang ke badan air.

\section{Kesimpulan}

Ada dua faktor pencemaran pada Sungai Musi di Kota Palembang, yaitu pencemaran akibat proses dari kegiatan domestik dan penyebab pencemaran yang berasal dari kegiatan industri. Karakteristik pencemaran di perairan Sungai Musi sebagian besar didominasi oleh dekomposisi organik pada air sungai menunjukan bahwa faktor sampah rumahtangga merupakan faktor determinan utama yang mencemari Sungai Musi. Tingginya kadar organik dalam perairan Sungai Musi dapat dilihat dari konsentrasi kadar TDS, Amoniak Total, Besi, Timbal, COD, BOD, DO dan konsentrasi bakteri colyform yang berada diatas ambang batas baik dari sungai bagian hulu maupun bagian hilir.

Pengelolaan limbah cair industri di Kota Palembang masih kurang mendapat perhatian. Limbah cair industri terutama industri besar sebagian diolah langsung oleh masing-masing industri dimana sistemnya sangat bergantung pada jenis limbah yang dihasilkan, namun demikian ada beberapa industri yang langsung membuang ke badan air. 


\section{Ucapan terimakasih}

Penulis mengucapkan terimakasih kepada Kementerian Riset Teknologi dan Pendidikan Tinggi yang sudah memberikan kesempatan untuk dapat melakukan penelitian. Ucapan terimakasih juga disampaikan kepada Direktorat Riset dan Pengabdian Masyarakat Direktorat Jendral Penguatan Riset dan Pengembangan Kementrian Riset, Teknologi, dan Pendidikan Tinggi yang telah memberikan pembiayaan. Ucapan terimakasih juga disampaikan kepada Rektor Universitas PGRI Palembang serta pihak LPPkM Universitas PGRI Palembang yang telah membantu dalam memfasilitasi seluruh kegiatan penelitian.

\section{Daftar Pustaka}

Agnes, A. R., \& Azizah, R. (2005). Perbedaan Kadar BOD, COD dan TSS. Jurnal Kesehatan Lingkungan, 2(1), 97-110.

Agustine, L., Sudirja, R., \& Harryanto, R. (2018). Identifikasi Sumberdaya Lahan Pada Ketersediaan Logam Berat (Pb, Cd Dan Cr) Tanah Sawah Di Daerah Pengairan Sungai Cikijing Kecamatan Rancaekek. Jurnal Teknologi Pertanian Andalas, 22(1), 22-31.

Aina, L. C., Endah, R. S. D., \& Kaswinarni, F. (2016). Biomonitoring Pencemaran Sungai Silugonggo Kecamatan Juwana Berdasarkan Kandungan Logam Berat $(\mathrm{Pb})$ pada Ikan Lundu. Bioma, 5(2), 1-11.

Aswadi, M., Riani, E., Pramudya, B., \& Kurniawan, B. (2019). Strategi Pengendalian Pencemaran Merkuri Dari Per-Tambangan Emas Rakyat Di Sungai Poboya, Kota Palu Yang Berkelanjutan. Jurnal Pengelolaan Sumberdaya Alam Dan Lingkungan, 9(1), 128-134.

Budiarta, I. G. (2014). Penegakan Sanksi Terhadap Pelanggaran Baku Mutu Limbah Cair Hotel Menurut UndangUndang Nomor 32 Tahun 2009 Sebagai Antisipasi Kemerosotan Kualitas Lingkungan Pantai Di Bali. Media Komunikasi Geografi, 15(2), 17-28.
Casali, J. R., Gimenez, J., Diez, J., Álvarez-Mozos, J. D. ., de Lersundi, M., Goni, M. A., ... Gastesi, J. L. (2010). Sediment Production and Water Quality of Watersheds with Contrasting Land Use in Navarre (Spain). Agricultural Water Management, 97, 1683-1694.

Christanto, N., Setiawan, M. A., Nurkholis, A., \& Istiqomah, S. (2018). Analisis Laju Sedimen DAS Serayu Hulu dengan Menggunakan Model SWAT. Majalah Geografi Indonesia, 32(1), 50-58.

Darmono. (2001). Lingkungan Hidup dan Pencemaran (Hubungannya dengan Toksikologi Senyawa Logam). Jakarta: UI Press.

Edward. (2014). Kandungan logam berat dalam sedimen di Perairan Teluk Wawobatu, Kendari, Sulawesi Tenggara. Depik, 3(2), 157-165.

Effendi, H. (2003). Telaah Kualitas Air Bagi Pengelolaan Sumber Daya dan Lingkungan Perairan. Yogyakarta: Kanisius.

Mahyudin, Soemarno, \& Prayogo, T. B. P. (2015). Analisis Kualitas Air Dan Strategi Pengendalian Pencemaran Air Sungai Metro di Kota Kepanjen Kabupaten Malang. J-PAI, 6(2), 105114.

Mamun, A. A., \& Zainudin, Z. (2013). Sustainable River Water Quality Management in Malaysia. IIUM Engineering Journal, 14(1), 29-42.

Setianto, H., \& Murjainah. (2019). Hubungan Pola Persebaran Permukiman Dengan Kualitas Airtanah di Kecamatan Plaju Kota Palembang. Jurnal Geografi, 16(1), 60-71.

Setyaningsih, W., Sriyono, \& Benardi, A. I. (2018). Kajian Kerusakan Lahan Di Daerah Aliran Sungai (DAS) Kreo Akibat Pembangunan Pemukiman Di Sekitar Waduk Jatibarang Kota Semarang. Media Komunikasi Geografi, 19(2), 177-186.

Yudo, S. (2010). Kondisi Kualitas Air Sungai Ciliwung di Wilayah DKI Jakarta ditinjau dari Parameter Organik, Amoniak, Fosfat, Deterjen dan Bakteri Coli. Jurnal Akuakultur Indonesia, 6, 34-42. 